\title{
LAKE GALLOCANTA (ARAgON, NE. SPAIN), A PARADIGM OF FLUCTUATIONS AT DIFFERENT SCALES OF TIME.
}

\author{
F. A. Comín, X. Rodó and P. Comín \\ Department of Ecology. University of Barcelona, Diagonal 645, 08028 Barcelona, Spain
}

Keywords: Saline lakes, Fluctuations, Time scales.

\begin{abstract}
Physical, chemical and biological characteristics fluctuate in many saline lakes at different scales of time. They are very adequate for studies of the structure and functioning of the biological community because changes in the species composition and biomass occur extremely related to changes of the physical and chemical characteristics of the water, which, in turn, respond to climatic fluctuations.

In Lake Gallocanta, a saline lake in NE Spain, water level changed from a maximum depth of $2 \mathrm{~m}$ in 1977 to $0 \mathrm{~m}$ (in fact the water level was between 10 and $30 \mathrm{~cm}$ below the ground) in 1985, and reached again a relatively high depth of $140 \mathrm{~cm}$ in 1991 . Seasonal fluctuations are also very clear. The chemical composition of the water is related to the water level. Seasonal fluctuations of total dissolved solids are inversely related to water volume in the lake. However, a more complex pattern of ionic composition and total dissolved solids is observed at a longer time scale (several years). Salts are lost selectively by precipitation and eolic erosion during dry periods. The relative abundance of different ions changes between years.

Fluctuations of organisms are illustrated by changes in the relationship between number of cells and number of species of phytoplankton from a several years. During periods of time of increasing water level-decreasing salinity the number of cells increases while the number of species decreases (relatively low K values). During periods of time of decreasing water levelincreasing salinity, relatively high values of $\mathrm{K}$ are found. The same pattern is observed at different scales of time: comparing trends during a series of years and seasonal changes. At the ecosystem level, a similar view is proposed: the relationships between living and non-living compartments are also submitted to fluctuations at different scales of time. The number of links are lower and their intensity higher during low water level-high salinity periods than during high water level-low salinity periods. The number and intensity of the links between compartments must change seasonally, annually and at higher scales of time in accordance with the fluctuations of chemical and physical variables.
\end{abstract}

\section{INTRODUCTION}

Saline lakes provide excellent conditions for ecological studies of aquatic ecosystems. Their community structures and energy flux networks are simpler than in freshwater ecosystems (HAMMER, 1986). They also provide highly valuable natural resources to humans (WILLIAMS, 1981). In spite of these advantages and the fact that the volume of inland saline waters in the world is quite similar to the volume of freshwaters (VALLENTYNE, 1972), only recently have saline lakes received adequate attention from the international limnological community. Fortunately, limnological studies of saline lakes proliferated all around the world after the initiation of a series of Symposia on

Limnetica, 8: 79-86 (1992)

O Asociación Española de Limnología, Madrid. Spain
Inland (Athalassic) Saline Lakes endorsed by SIL (WILLIAMS, 1981, HAMMER, 1983, MELACK, 1988, COMIN \& NORTHCOTE, 1990, HURLBERT, in press).

Fluctuations in water level, as a consequence of meteorological changes, occur in saline lakes at different time scales. Consequently, changes in the biological communities related to physical and chemical characteristics occur in saline lakes more often and more intensely than in freshwater lakes. Adaptation to fluctuations rather than to ranges or precise values of physical and chemical variables must be acomplished by populations in order to survive (BROCK, 1986). Examples of saline lakes fluctuating at different frequencies and intensities range from lakes which only fill up ocasionally (Eyre, WILLIAMS \& KOKKIN, 1988) to 
permanent lakes (Pyramid, GALAT et al., 1990). Spanish saline lakes present a great variety of geomorphological characteristics and are located in different climatic regions (fig. 1) (COMIN \& ALONSO, 1988). Water level fluctuations also occur in Spanish saline lakes with diverse frequency and intensity (fig. 2). Lake Gallocanta is an example of a lake in which fluctuations in the water level can be clearly observed at different scales of time (fig. 2). Consequently, the chemical characteristics of the water, the structure of the biological community and, moreover, the functioning of the entire ecosystems also fluctuate at different time scales. Here, this view is developed reviewing data obtained in studies carried out irregularly during the last fourteen years as a way to propose long-term studies of ecosystems of this type.

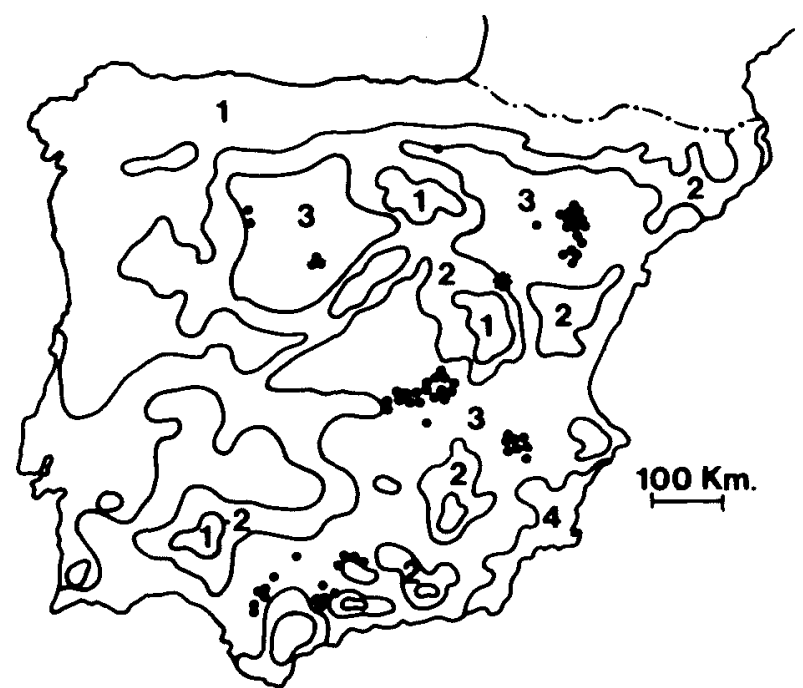

Figure 1. Location of most of the Spanish saline lakes in different climatic regions. 1-Humid, 2-Semihumid,3-Semiarid, 4-Arid. The asterisk indicates the location of Lake Gallocanta.

\section{GEOGRAPHICAL SETTING}

Lake Gallocanta is located at $987 \mathrm{~m}$ a.s.l. in the central part of the Iberian Range ( $40050^{\prime} \mathrm{N}, 2^{\circ} 11^{\prime} \mathrm{W}$ ), at the limit between semiarid and semihumid weather, with an average anuual precipitation of $440 \mathrm{~mm}$ which also undergoes wide seasonal and interannual fluctuations (COMIN et al., 1990). Lake Gallocanta represents the level of the water table at the hydrological terminus of a $520 \mathrm{~km}^{2}$ watershed. The present features of the watershed developed from a previously much wider area originated tectonically at the end of the Pleocene (HERNANDEZ \& ARANEGUI, 1926) . During the Quaternary period karstification and dissolution of triassic evapo- rites gave rise to the present saline conditions of the lake (GRACIA, 1990).

Lake Gallocanta was long considered a closed endorheic area. Recent studies calculated indirectly a net export of Gallocanta groundwater towards nearby watersheds. The groundwater export would account for between 5-30\% of the total renewable groundwater (CRUZ et al., 1979, TRAGSA. 1988)

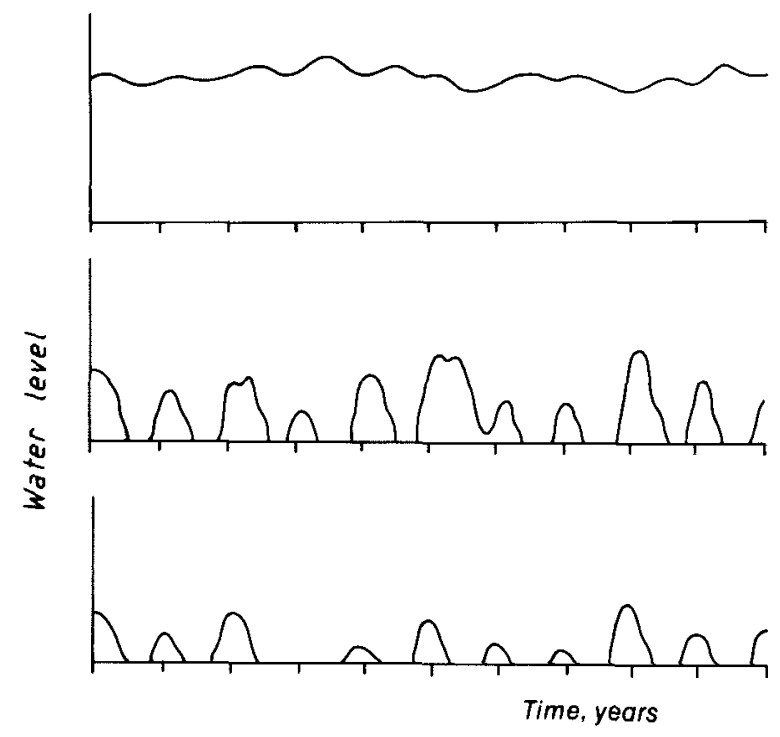

Figure 2. Idealized types of above ground water level fluctuations occurring in Spanish saline lakes during the last years: top, permanent saline lake; middle, saline lake which persisted inundated during one dry season; bottom, saline lake which remained dry during one wet season.

\section{SALINITY VERSUS WATER LEVEL FLUCTUATIONS}

The water level in Lake Gallocanta fluctuates at different scales of time (fig. 3) as a consequence of interannual changes of precipitation. Seasonal fluctuations are overlapped by medium and long term fluctuations. At a time scale smaller than the seasonal the number of fluctuations increases, although it is clear that the changes in water level at these intervals of a few days are of the order of $\mathrm{mm}$ and $\mathrm{cm}$. So, it is clear that there is an indirect relationship between intensity and frequency of water level changes, as for any disturbance in any ecosystem (MARGALEF, 1991).

There is no direct relationship between annual precipitation and water level. Water level fluctuations are related to precipitation through complex interactions because of the way water must run through the watershed (above and below 


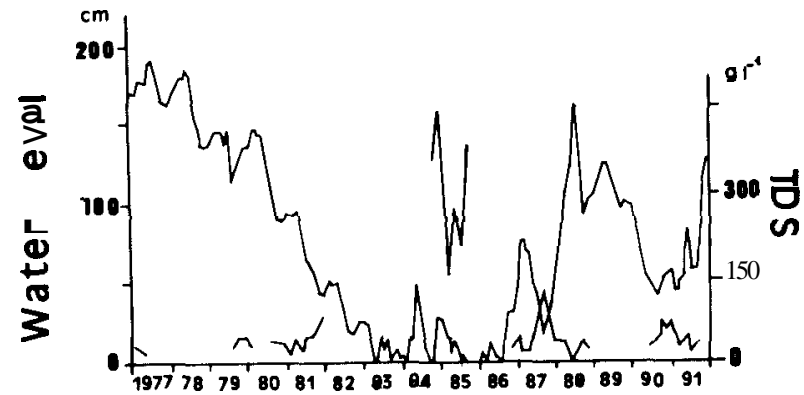

Figure 3. Water level and total dissolved solids recorded in Lake Gallocanta over time during a series of years.

ground) and the high evaporation rates. A response time of the water to rainfall between 0.3-2.4 years was calculated according to LANGBEIN (1961). This means that major changes in the seasonal pattern of rainfall (or in the water outflows) will cause marked lake level fluctuations after two years if the water level remained relatively stable for several years, and after four months if the water level fluctuated during the previous years (COMIN et al., 1991).

$A$ general inverse relationship exists between water level and salinity (fig. 3). However, fig. 4 gives a clearer picture of indicators of intense changes in the water characteristics after seasonal and longer fluctuations of the water volume. The comparison of concentrations at times of different years with identical water volume shows that the total amount of salts in aboveground lake waters decreases during dry periods (19831986) and increases during refilling periods (1987-91).
Similar differences, although less intense, occur during seasonal fluctuations of the water level. Precipitation of salts and accumulation in the sediments, which occurs with spatial heterogeneity, and wind deflation are responsible for the loss of large amounts of salts (COMIN et al., 1991). Redissolution of salts accumulating at the surface of the sediments and, most important, washed up by water flowing through (bottom-up) the sediments (COMIN \& FORES, 1990) incorporate salts from the solid to the dissolved phases.

Relationships of major ions dissolved in the water (chloride, sulphate, carbonate plus bicarbonate, sodium, magnesium, calcium, potassium) also show changes over time (table 1). Differences related to conservative changes (e.g., linear relationship with chloride concentration) indicate the intensity of biogeochemical processes which can be important in the lake waters (e.g.: differential precipitation, sulphate reduction) (COMIN et al., 1990, 1991).

\section{POPULATION FLUCTUATIONS}

Seasonal fluctuations in the biological community were extremely clear and intense in Lake Gallocanta during one year (1980-81) within the drying phase (fig. 3) (COMIN et al., 1983). Longer term fluctuations are still under study.

A quick and simple examination of the composition of a part of the biological community, the phytoplankton, at different years reveals important differences, both in specific composition and abundance. A change in the structure of

Table 1. Total dissoved solids $\left(\mathrm{g} \mathrm{l}^{-1}\right)$ and $\mathrm{Cl} / \mathrm{SO}_{4}$ ratio (meq/meq) in Lake Gallocanta during two years, before (1980-81) and just after (1986-87) a complete drought of the Lake.

\begin{tabular}{lcccc}
\hline & \multicolumn{2}{c}{$1980-1981$} & & $1986-1987$ \\
& TDS & $\mathrm{Cl} / \mathrm{SO}_{4}$ & TDS & $\mathrm{Cl}_{4} / \mathrm{SO}_{4}$ \\
\hline November & 39.4 & 3.81 & 37.7 & 4.07 \\
December & 37.7 & 3.51 & 48.5 & 4.41 \\
February & 46.5 & 3.61 & 29.1 & 4.23 \\
March & 40.7 & 3.74 & 21.5 & 3.79 \\
April & 36.1 & 3.11 & 26.1 & 3.93 \\
May & 39.7 & 3.96 & 31.1 & 3.77 \\
June & 49.6 & 4.35 & 43.5 & 3.52 \\
July & 77.2 & 3.77 & 55.2 & 3.61 \\
August & 79.2 & 3.57 & 73.9 & 3.62 \\
September & 95.3 & 3.58 & 134.1 & 4.39 \\
October & 100.9 & 3.41 & 147.1 & 4.51 \\
\hline
\end{tabular}




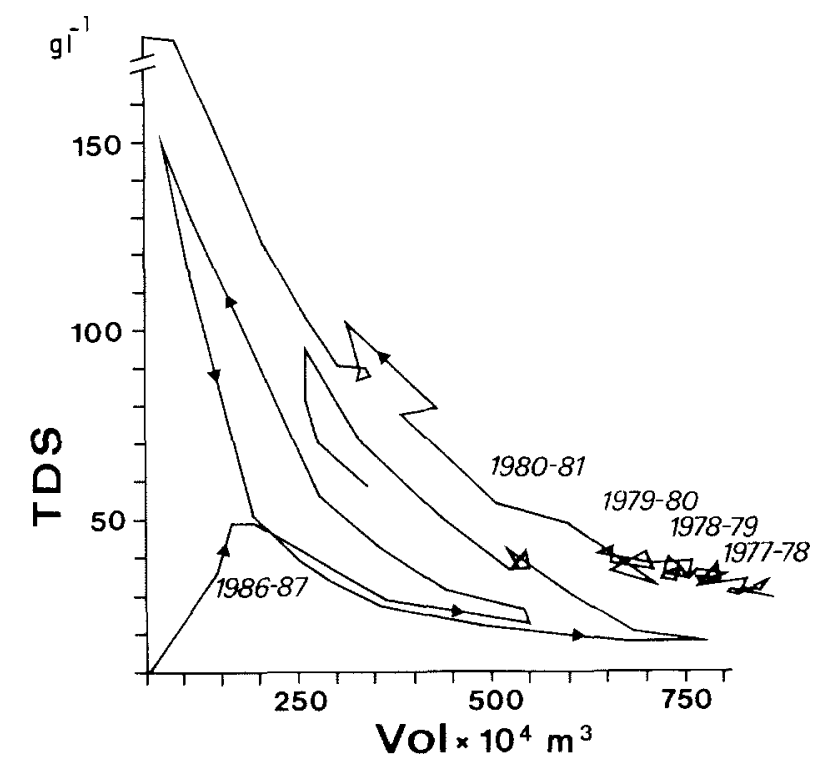

Figure 4. Total dissolved solids versus water volume in Lake Gallocanta.

this biological association is clearly observed from the changes in the abundances of the different species and from the change in the species richness. The number of species decreases as salinity increases, which has been a clear observation for many years (HAMMER, 1986), although it must be related to the time scale used for the observations (WILLIAMS et al., 1990).

A different approach may be more realistic: observations of fluctuations at different scales of time (and space) are necessary for the ecological interpretation of saline lake ecosystems (COMIN et al., 1991). This is supported by data on phytoplankton from different years, represented graphically in fig. 5. Most of the data correspond to two hydrological years (September 1980-October 1981 and November 1986-December 1987), during which salinity fluctuated in a similar range. Data from other years, which can be seen in Figs. 2 and 4, are also represented in fig. 5 .

The combination of number of species $(\mathrm{S})$ and total number of individuals, phytoplankton cells, $(\mathrm{N})$, is a measure of the structure of this part of the communiiy. Changes in the space defined by these two variables are a dynamic approach to the structural changes of the community, orto any diversity index, such as $\mathrm{K}=\lg \mathrm{S} / \mathrm{lg} \mathrm{N}$ proposed by MARGALEF (1989).

In our case, it is clear that the structure of the community in 1986-87 was simpler than in 1980-81: the cloud of points representing the phytoplankton structure in 1986-87 occupy a space on the upper-left side of the cloud of points corresponding to the phytoplankton in 1980-81. In other words, the diversity of the phytoplankton was lower in 1986-87 than in 1980-81. Moreover, in 1986-87 phytoplankton consisted of fewer species with more differences between the specific abundances than in 1980-81.
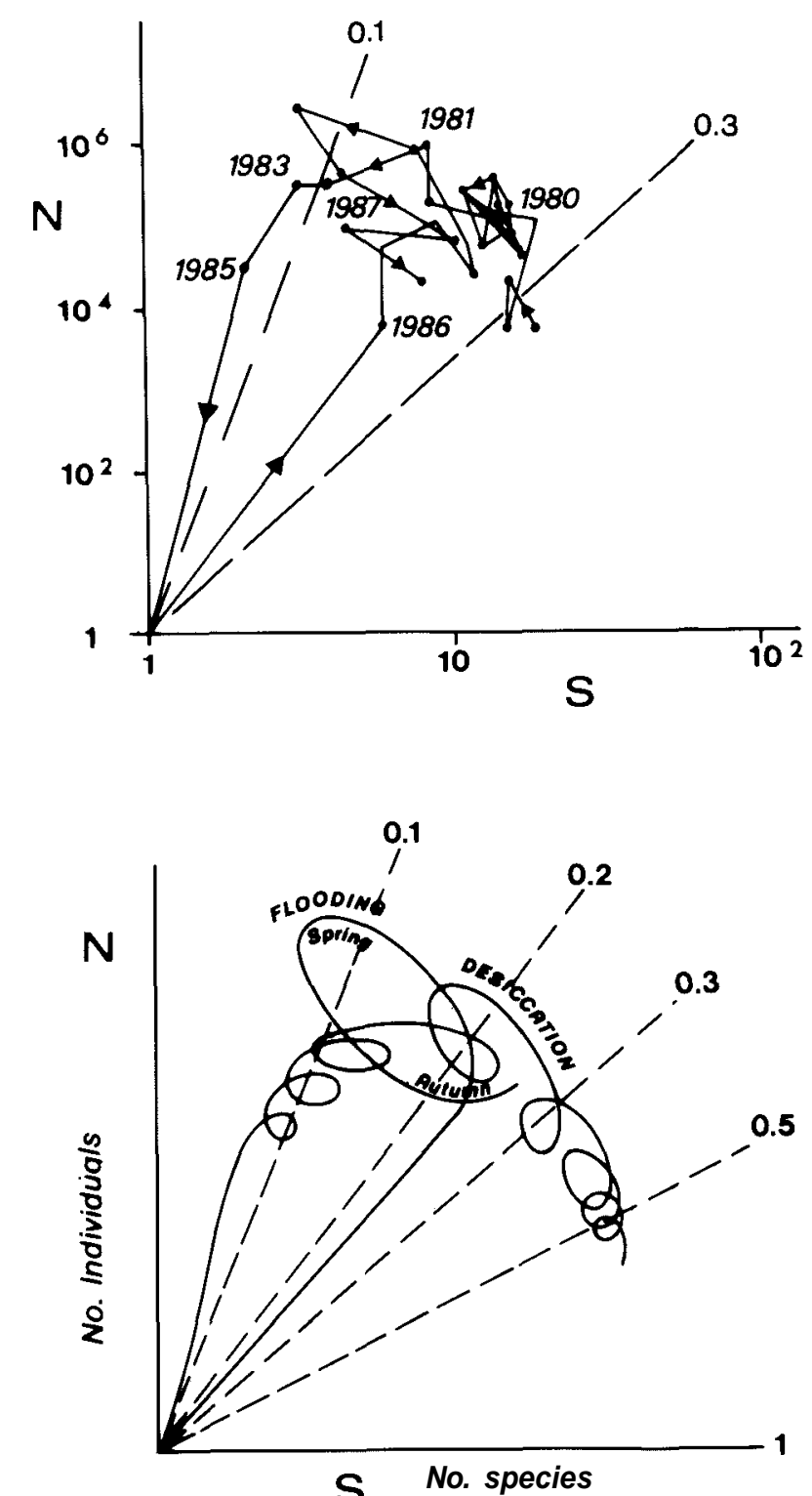

Figure 5. Number of individuals versus number of species of phytoplankton in Lake Gallocanta for a series of years. Top, representation of actual data; bottom. idealized changes from the top graph. Discontinuous lines indicate several values of $\mathrm{K}=\log \mathrm{S} / \log \mathrm{N}$ (MAKGALEF, 1989). 
Fig. 5 also shows that the amplitude of the changes in the phytoplankton structure was wider in 1986-87 than in 198081 . It corresponds to the characteristics of the community after an intense perturbation like the dryness of the lake, which was beginning its self organization, the early stages of ecological succession. In some way, this change of structure during a fluctuation is the same type of dynamic change a community follows through time (e.g.: seasonal cycles in temperate ecosystems). In fig. 5, points corresponding to spring data lie on the ascendent left side and points corresponding to fall data lie in the descendent-right side of the loops (MARGALEF, 1989). This corroborates the hypothesis expressed before: each of the seasonal fluctuations in Lake Gallocanta follows a different trajectory. However, these seasonal trajectories are loops within a longer trajectory. The few available data of 1982 and 1985 pointed out in fig. 5 allow us to form an image of the trajectory of the structure of phytoplankton, which would correspond to the fluctuation at longer time scale represented in fig. 2. Again, the biological structure fluctuates at different time scales in Lake Gallocanta. We can easily imagine similar trajectories for each fluctuation between dry periods, Lake Gallocanta has dried up four times this century (GUIRAL, 1981), or even at longer, geological, scale.

\section{COMMUNITY FLUCTUATIONS}

Like phytoplankton, every component of the ecosystem fluctuates in Lake Gallocanta at different time scales. Moreover, the relative importance of the relationships between the components of the biological community and of those with abiotic factors also changes with time. So, fluctuations at different scales of time must also be shown by the energy and trophic ecosystem metworks. This is a suggestion that we will now discussed simply on the evidence of direct observations for a number of years and some data from other saline lakes.

Let us first begin with a simple comparison of several differences that have been observed in Lake Gallocanta between a high water level-low salinity stage (e.g., 1977) and a low water level-high salinity stage (e.g., 1981). Some of these differences have been clearly explained by De DECKKER (1988), who pointed out three basic phases or groups of salt lakes according to their biological and sedimentary facies: wet phases of ephemeral shallow lakes, dry lakes and deep water lakes. In Lake Gallocanta, during a high water level-low salinity stage, phytoplankton and rooted submerged macrophytes are very important, both in biomass and dynamic roles, providing energy for other trophic levels. Zooplankton biomass is lower than phytoplankton. Dense populations of macroinvertebrates live in association with the macrophytes and in the sediments. A great variety of birds are present in the lake reaching very high densities. E.g.: the number of aquatic birds observed during winter 1978-79 was $148,892 \pm 23,410$, while during winter $1980-81$ it was $52,825 \pm 24,728 \quad(n=5$, census carried out inonthly from October to February) (HERNANDEZ et al., 1981). Rooted submerged macrophytes also develop high biomass populations during high water level phases (COMIN et al., in press), a balance for the entire ecosystem would give production over respiration, which would be predominantly aerobic. during high water level-low salinity stages.

During low water level periods, huge amounts of organic matter accumulate in the lake bottom and shores. At low water level-high salinity stages, the biomass of consumers (e.g., zooplankton) is higher than the biomass of producers on which they feed (e.g., phytoplankton) for short periods of time (one month) (GARCIA, 1991). However, considering a longer period of time, the biomass ratio (phytoplankton/zooplankton) reaches an equilibrium close to 1 , the lowest limit proposed by SHELDON et al.(1977) for pelagic systems. Enormous microbial mats developed in Lake Gallocanta in summer 1981 and huge amounts of decomposing filamentous algae accumulated on the shores and bottom and in the water column of Lake Gallocanta during summer 1990 and 1991. Then respiration, mostly anaerobic, would overcome production during these stages. After this simplistic comparison it is necessary, following the point of view expressed before, to address the changes in the relationships between components of the ecosystem as fluctuations at different scales of time, like those described for phytoplankton or salinity above. For example, it is clear that most of the diet of the bird populations in Lake Gallocanta consists of rooted submerged macrophytes. However, during periods of macrophyte decline (1981), the proportion of the energy obtained by birds from a variety of insects living in the waters and seeds of terrestrial plants close to the shoreline increases (GUIRAL, 1981). Moreover, the total nuniber of birds decreases as macrophyte beds decline (HERNANDEZ et al., 1981).

Seasonal fluctuations in rnacrophytes are very clear. During a series of years of low water level-high salinity (e.g.,199091), two populations of rooted submerged macrophytes (Ruppia drepanensis and Lampr-othamnium papulosum) grew 
very quickly during winter-spring time, reached a relatively low biomass and died, decomposing during summer while salinity was increasing. The interesting point is that the spatial distribution (studied in a transect perpendicular to the shoreline) of the macrophyte populations was changing along the growing season. Large shores appeared as the water level decreased. Drying-flooding cycles of these shores, which is relatively frequent at these low water level stages, stimulate the microbial activity and enhance the mineralization of nutrients (AGARWAL et al., 1971, HOWARD-WILLIAMS, 1972). The lake sediment became progressively anoxic as organic matter accumulated and decomposed on it and, supposedly, the sediment-water exchanges were enhanced.
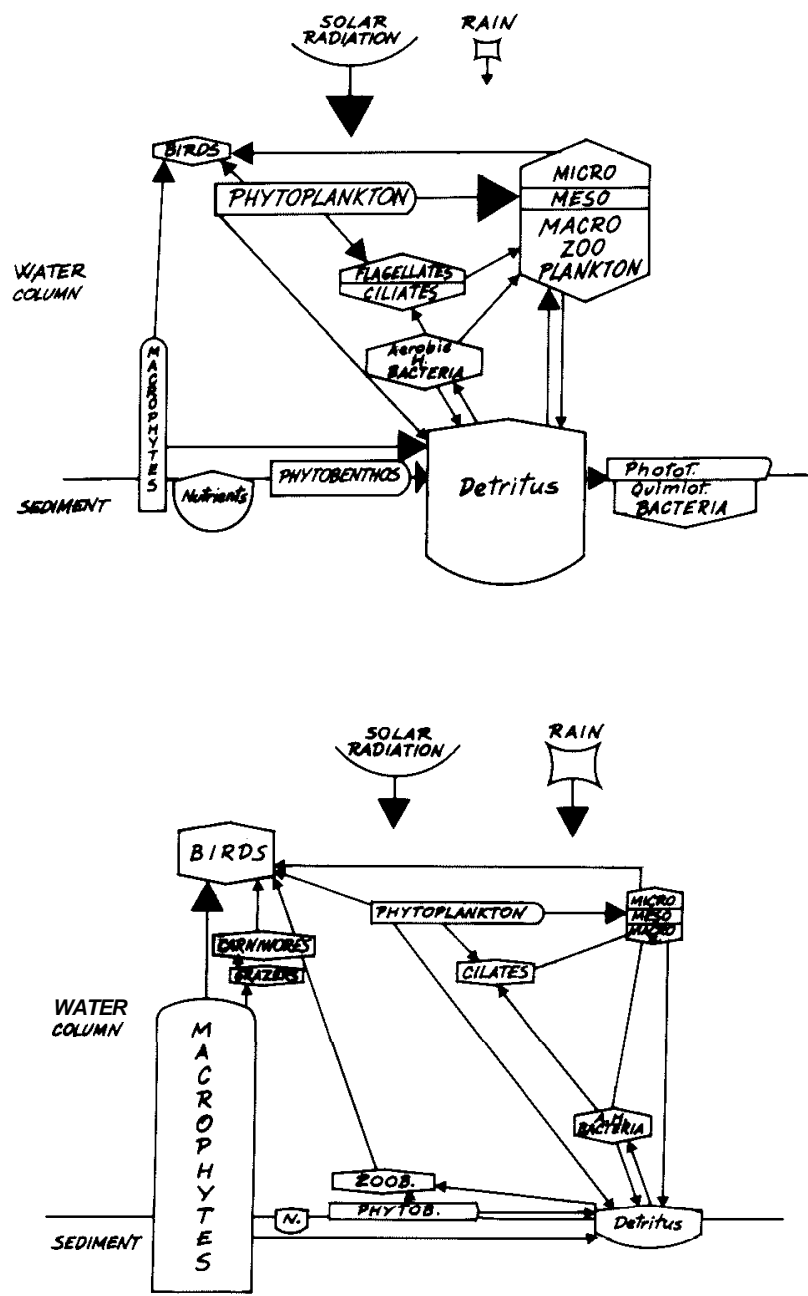

Figure h. Schematic representation of the relationships between compartments of Lake Gallocanta at two different stages:top, low water level-high salinity; bottom, high water level-low salinity.
During years of high water level-low salinity, macrophyte populations also show seasonal fluctuations. However, dense stands remain during summer, fall and winter. The atructure of the sediments remain with fewer changes because the root system and relationships between sediment and water column and between macrophytes and consumers are not submitted to such marked seasonal changes as during low water level stages.

Probably, the number of links (connections between living and/or non living compartments of the system) decreases and their intensity (energy transfers) increases during low water level phases and viceversa during high water level phases (fig. 6). Again, we suppose that these relationships fluctuate at different scales of time in Lake Gallocanta. Evidently, the amount of research which is now waiting to be done is overwhelming.

\section{FUTURE PERSPECTIVES}

The work presented here was carried out with the same characteristics mentioned by STRAYER et al. (1986) for other long-term studies. A serendipitous combination of dedicated scientists, the opportunity (site and ideas) and funding (fluctuating at different time scales) made it possible to sample Lake Gallocanta at irregular intervals. These efforts provided data which were very useful for partial interpretation of ecological processes. However, the number of ideas for future studies after each partial approach rose quickly. All the potential subjects of limnological research in Lake Gallocanta had a common link: observations at different time scales are necessary for a correct interpretation of phenomena.

In other words, Lake Gallocanta presents phenomena for which long-term studies are recognized as essential for a correct understanding. For example, for seven years (197783) water level showed a net decreasing trend (fig. 2). During this period, a study lasting just one year would not have shown this trend, nor some of its ecological consequences (e.g.: macrophyte and bird population changes).

This is a common feature of some saline lakes where it has been observed that fluctuations of physical, chemical and biological characteristics occur clearly defined at different scales of time. The same types of slow process must occur in Lake Chilwa, where similar types of fluctuations were recorded (KALK et al., 1979).

Lake drying up is a rare event which has happened once in the 15 year series recorded here for Lake Gallocanta. 
Sudden refilling of usually dry lakes (Lake Eyre, WILLIAMS \& KOKKIN, 1988) or permanence of water all the year round in lakes which usually dry up every year (Lake Fuente de Piedra, GARCIA, 1991) are also examples of episodic phenomena. However, lakes of these types do not offer the wide range of fluctuations, both in frequency and intensity, which make a saline lake particularly suitable for long-term studies. Processes with high variability also require long-term periods of observations to describe all the variability range. This is the case of saline lakes where salinity and the biological community change over a wide range but they take several years to fluctuate within the entire range. Long-term series of data are also important to sort out the relative contribution of different factors involved in complex ecological phenomena (e.g.: temporal and spatial pattems of macrophyte distribution, COMIN et al., in press).

Once we are convinced of the necessity of long-term studies to understand saline lake ecosystems fluctuations, it is necessary to couple long-term data collecting with the formulation of ecological hypotheses (RISSER, 1991). This is necessary to justify the expenses of long-term studies. One needs to persuade to funding entities that the work will be useful and one should try to contribute to general ecological theory, or at least to test some ecological concepts. This is easy because many hypotheses arise soon after the first observations.

Saline lakes commonly act as useful recorders of climatic changes because many fossil remains are preserved in the sediments (De DECKKER, 1988). In addition, the high sedimentation rates of saline lakes favor reconstructions on long and short time scales, as the behaviour of these aquatic systems may be inferred during periods of climatic change. However, the biological remains are not well preserved in all the sediments because some chemical and geological processes alter their mineral components (De DECKKER, 1988). The key point is to find out the function to transfer from sedimentary records to changes in the past characteristics of the lake and of these with the hydrological regime. This has been successfully done by FRITZ (1990) with data from Lake Devils, North Dakota (USA) recorded for the last 100 years. She asserted “...saline lake sediments are probably unparalleled as tools for paleohydrologic and paleoclimatic reconstruction in arid and semiarid regions", and many authors agree with her. From these types of study forecasts for future changes in saline lakes and wetlands can be inferred and, consequently, suggestions for water use and land management can be developed.

Ecological succession (changes in the community structure through time, self-organization versus external regula- tion) and the controls of production in aquatic ecosystems (allocthonous versus autocthonous, planktonic vs. benthic, aerobic vs. anaerobic processes) are major subjects in Ecology. Many saline lakes provide excellent conditions to check regularities because: i- they are quite closed systems compared to other aquatic ecosystems and, consequently, boundaries can be better defined; ii- the shallowness of the water and the flatness of the bottom permit quite acceptable integrations at the ecosystem level. Moreover, because of these previous characteristics and the excellent coupling between hydrogeological and biological changes, the variabilities of different processes are well correlated or, at least, can be satisfactorily undertaken with little effort per unit of time, although, we insist, long-term records are necessary.

\section{ACKNOWLEDGEMENTS}

Thanks are given to Diputación General de Aragón (Servicio de Conservación del Medio Natural), which sponsored most of the work presented here. One of the authors (X. R.) was in receipt of funds (F.P.I. grant) from the Spanish Ministry of Education and Science.

\section{REFERENCES}

AGARWAL, A.S., B.R. SINGH \& Y. KANEHIRO, 1971. Soil nitrogen and carbon mineralization as affected by dryingrewetting cycles. Soil Sci. Soc. Amer. Proc. 35: 96-100.

BROCK, M. A., 1986. Adaptation to fluctuations rather than to extremes of environmental parameters. In: P. De Deckker \& W.D. Williams (Eds.). Limnology in Australia: 131-140. Dr. W. Junk Publishers. Dordrecht.

COMIN, F.A., M. ALONSO, P. LOPEZ \& M. COMELLES, 1983. Limnology of Gallocanta Lake, Aragón, NE. Spain. Hydrobiologia 105: 207- 221.

COMIN F.A. \& M. ALONSO, 1988. Spanish salt lakes: their chemistry and biota. Hydrohiologia 158: 237-245.

COMIN, F.A. \& T.G. NORTHCOTE (eds.), 1990. Suline Lakes. Developments in Hydrobiology 59, 324 pp.

COMIN, F.A. \& E. FORÉS, 1990. Comprobación experimental de la importancia relativa de las vías superficial y subterránea de inundaciòn en la liberación de sales de sedimentos desecados. Scientia gerundensis 16: 69-77.

COMIN, F.A., R. JULIA, M.P. COMIN \& F.PLANA, 1990. Hydrogeochemistry of Lake Gallocanta (Aragón, NE. Spain). Hydrobiologia 197: 51-66. 
COMIN, F.A., R. JULIA \& P. COMIN, 1991. Fluctuations. the key aspect for ecological interpretation of saline lake ecosystems. Oecologia Aquatica 10: 127-135.

COMIN, F.A., X. RODO \& M. MENENDEZ. (in press). Spatial heterogenity of macrophytes in Lake Gallocanta. Hydrobiología.

CRUZ, J., J.G. DOBLAS \& M. GARRIDO, 1979. Hidrogeología de la Laguna de Gallocanta. Actas $2^{\circ}$ Simp. Nac. Hidrogeol., Secc. 1ㄴ Hidrogeol., 4: 431-446. Asoc. Geol. Esp. Minist. Obras Publ.

DE DECKKER, P., 1988. Biological and sedimentary facies of Australian salt lakes. In: Paleolimnology, aspects of freshwater paleoecology and biogeography (J. Gray, ed.): 237- 270. Elsevier Science Publ., Amsterdam.

FRITZ, S. C., 1990. Twentieth-century salinity and water level fluctuations in Devils Lake, North Dakota: Test of a diatom based transfer function. Limnol. Oceanogr. 35: 1771-1781.

GALAT, D.L., J.P. VERDIN \& L.L. SIMS, 1990. Large scale patterns of Nodularia spumigena blooms in Pyramid Lake, Nevada, determined by Landsat imagery: 1972-1986. Hydrohiologia 197: 147-164.

GARCIA, C., 1991. Estudio de un medio acuático fluctuante: La laguna atalasohalina de Fuente de Piedra (Málaga). (Unpublished Ph. D. Thesis). University of Málaga, 296 pp.

GRACIA, F.J., 1990. Geomorfología de la región de Gallocanta (Unpublished Ph. D. Thesis). University of Zaragoza, $660 \mathrm{pp}$.

GUIRAL, J.J., 1981. Introducción al estudio de la alimentación de las anátidas y fochas de la laguna de Galocanta. In: Estudio de la hiocenosis de la laguna de gallocanta y su cuenca. (PROYEX, S.A., ed.): 708-740. ICONA. Madrid.

HAMMER, U.T.(ed.), 1983. Saline Lakes. Developments in Hydrohiology 105, 263 pp.

HAMMER, U.T., 1986. Saline Lake Ecosystems of the world. Dr. W. Junk Publ. Dordrecht. 616 pp.

HERNANDEZ, E. \& P. ARANEGUI, 1926. La laguna de Gallocanta y la geología de sus alrededores. Bol. r. Soc. Esp. Hist. Nat. 26: 419-429.

HERNANDEZ, F., M. BURGUETE \& J.J. GUIRAL, 1981. Estudio de la dinámica de las poblaciones de aves acuáticas de la laguna de Gallocanta. In: Estudio de la biocenosis de la laguna de Gallocanta y su cuenca (PROYEX, S.A., ed.): 594-644. ICONA. Madrid.
HOWARD-WILLIAMS, C., 1972. Limnological studies in an african swamp: seasonal and spatial changes in the swamps of Lake Chilwa, Malawi. Arch. Hydrobiol. 70: 379-391.

HURLBERT, S. H. (ed.), (in press.). Saline Lakes. Developments in Hydrohiology.

KALK, M., A.J. MCLACHLAN \& C. HOWARDWILLIAMS (eds.), 1979. Lake Chilwu, studies of change in a tropical ecosystem. Monographiae Biologicae 35, 462 pp. Dr. W. Junk Publ. Dordrecht.

LANGBEIN, W.B., 1961. Salinity and hydrology of closed lakes. USGS Prof. Paper 412, 220 pp.

MARGALEF, R., 1989. On diversity and conectivity as historical expressions of ecosystems. Coenoses 4(3):121-126.

MARGALEF, R., 1991. Teoría de los sistemas ecológicos. Estudi General 1, 290 pp. Publ. Univ. Barcelona.

MELACK, J.M.(ed.), 1988. Saline Lakes. Developments in Hydrohiology 158, 316 pp.

SHELDON, R.W., W.H. SUTCLIFFE \& M.J. PARANJAPE, 1977. Structure of pelagic food chain and relationship between plankton and fish production. J. Fish. Res. Bd. Can. 34:2344-2353.

STRAYER, D.J., GLITZENSTEIN, C.G. JONES, J. KOLASA, G.E. LIKENS, M.J. MCDONELL, G.G. PARKER \&S.T.A. PICKETT, 1986. Long-term ecological studies: an illustrated account of their design, operation, and importance to ecology. Occasional Publications 1. Institute of Ecosystem Studies. New York.

TRAGSA, 1988. Estudio de los recursos hídricos de la Laguna de Gallocanta y acciones para su conservación. ICONA, Minist. Agric. Pesca y Alim., 310 pp.

VALLENTYNE, J.R., 1972. Effects of the demophoric explosion on water and Man. In: The Environmental Future (POLUnin, N., ed.): 406-414. The MacMillan Press. London. $660 \mathrm{pp}$.

WILLIAMS, W.D. (ed.), 1981. Salt Lakes. Developments in Hydrohiology 5, 444 pp.

WILLIAMS, W.D. \& M.J. KOKKIN, 1988. The biogeographical affinities of the fauna in episodically filled salt lakes: A study of Lake Eyre South, Australia. Hydrobiologia 158:227-236.

WILLIAMS, W.D., A.J. BOULTON \& R.G. TAAFFE, 1990. Salinity as a determinant of salt lake fauna: a question of scale. Hydrohiologia 197: 257-266. 